\title{
Commentary: Is the right ventricle an innocent bystander in pulmonary resection?
}

\author{
Sandra L. Starnes, MD
}

\footnotetext{
From the Division of Thoracic Surgery, Department of Surgery, University of Cincinnati College of Medicine, Cincinnati, Ohio.

Disclosures: Author has nothing to disclose with regard to commercial support.

Received for publication Feb 1, 2019; accepted for publication Feb 1, 2019; available ahead of print March 12, 2019.

Address for reprints: Sandra L. Starnes, MD, John B. Flege Jr Chair in Cardiothoracic Surgery, University of Cincinnati College of Medicine, 231 Albert B. Sabin Way, MC 0558, Cincinnati, OH 45267 (E-mail: sandra. starnes@uc.edu).

J Thorac Cardiovasc Surg 2019;158:566-7

$0022-5223 / \$ 36.00$

Copyright (C) 2019 by The American Association for Thoracic Surgery

https://doi.org/10.1016/j.jtcvs.2019.02.006
}

In this issue of the Journal, McCall and colleagues ${ }^{1}$ report a study in which they used cardiovascular magnetic resonance to undertake a comprehensive assessment of changes in right ventricular (RV) and pulmonary arterial (PA) function in 27 patients undergoing lobectomy. They demonstrated that RV function declined postoperatively and remained decreased from preoperative values at 2 months, with a mean decrease in RV ejection fraction (RVEF) of $10 \%$, whereas left ventricular function remained preserved. Interestingly, four patients had a decline in RVEF greater than $20 \%$. This is a very interesting article, representing as it does the first comprehensive study of RV and PA function after lobectomy using cardiovascular magnetic resonance. The limitations are well noted by McCall and colleagues, ${ }^{1}$ in that the sample size is very small and no significant clinical implications could be drawn from the data.

There has been little reported in the literature regarding $\mathrm{RV}$ function after pulmonary resection, likely because an invasive technique was previously required for accurate measurement. Okada and coworkers ${ }^{2}$ demonstrated a mean decrease in RVEF of $21 \%$ in patients undergoing anatomic pulmonary resection, which remained depressed at 3 weeks. They also demonstrated that patients had a persistent elevated heart rate and pulmonary arterial pressure with exercise that was not seen at rest. This same group $^{3}$ revealed that patients who had an exercise-induced decrease in RVEF preoperatively had an increased likelihood of complications postoperatively, but preoperative RVEF at rest did not predict complications. Both of these studies used pulmonary arterial catheters and included fewer than 20 patients.

The potential implications of the current article of McCall and colleagues ${ }^{1}$ are intriguing. The use of cardiovascular magnetic resonance allows accurate and noninvasive measurement of RV and PA function. This study is a first step in evaluating the utility of this modality in the

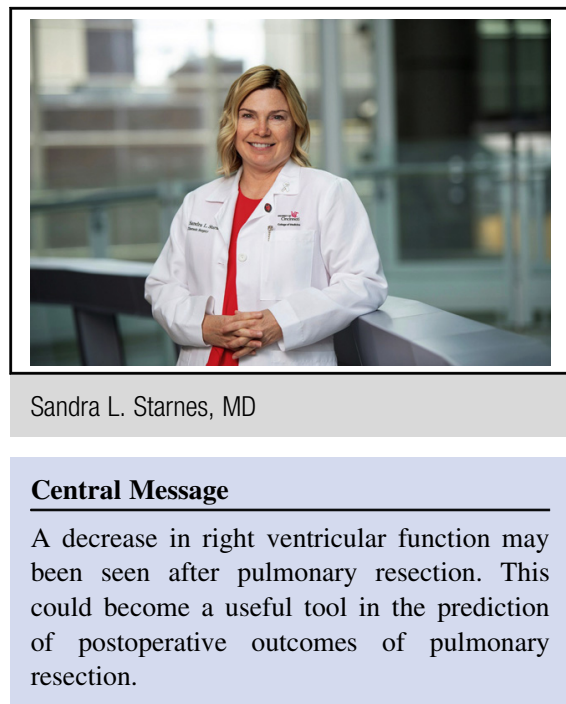

See Article page 556. evaluation of thoracic surgery patients. With larger studies, determination of a correlation between changes in RV and PA function and postoperative complications might be possible. More interesting would be an association between RV and PA functional changes and quality of life outcomes, such as functional status and exercise capacity. Recent efforts have focused on predicting these long-term outcomes in patients after pulmonary resection. Standard pulmonary function testing has been shown to be a poor predictor of changes in exercise capacity and quality of life. ${ }^{4,5} \mathrm{We}$ have all seen patients who have a surprisingly poor exercise capacity after anatomic resection that was not expected on the basis of preoperative pulmonary function. On the flip side, patients with marginal pulmonary function often tolerate resection with acceptable morbidity. ${ }^{6}$ A better understanding of the effect of surgical resection on factors that are important to patients is critical as we move into the future, especially in light of the increasing use of nonsurgical treatments for early-stage lung cancer, such as stereotactic body radiotherapy. In fact, linking patient-reported outcomes to the Society of Thoracic Surgeons Database has been proposed, which will make the database even more powerful and continue to place thoracic surgeons at the forefront in the care of patients with lung cancer. ${ }^{7}$ 


\section{References}

1. McCall PJ, Arthur A, Glass A, Corcoran DS, Kirk A, Macfie A, et al. The right ventricular response to lung resection. J Thorac Cardiovasc Surg. 2019;158: 556-65.e5.

2. Okada M, Ota T, Okada M, Matsuda H, Okada K, Ishii N. Right ventricular dysfunction after major pulmonary resection. J Thorac Cardiovasc Surg. 1994;108:503-11.

3. Okada M, Okada M, Ishii N, Yamashita C, Sugimoto T, Okada K, et al. Right ventricular ejection fraction in the preoperative risk evaluation of candidates for pulmonary resection. J Thorac Cardiovasc Surg. 1996;112:364-70.

4. Larsen KR, Svendsen UG, Milman N, Brenøe J, Petersen BN. Cardiopulmonary function at rest and during exercise after resection for bronchial carcinoma. Ann Thorac Surg. 1997;64:960-4.
5. Brunelli A, Socci L, Refai M, Salata M, Xiumé F, Sabbatini A Quality of life before and after major lung resection for lung cancer: a prospective follow-up analysis. Ann Thorac Surg. 2007;84: 410-6.

6. Taylor MD, LaPar DJ, Isbell JM, Kozower BD, Lau CL, Jones DR. Marginal pulmonary function should not preclude lobectomy in selected patients with nonsmall cell lung cancer. J Thorac Cardiovasc Surg. 2014;147:738-44; discussion 744-6.

7. Khullar OV, Rajaei MH, Force SD, Binongo JN, Lasanajak Y, Robertson S, et al. Pilot study to integrate patient reported outcomes after lung cancer operations into the Society of Thoracic Surgeons database. Ann Thorac Surg. 2017; 104:245-53. 